\title{
Causes and consequences of nest mass and structure variation in the Bay-capped Wren-spinetail Spartonoica maluroides
}

\author{
Daniel Augusto CARDONI*, Juan Pablo IsACCH \& Alejandro BALADRÓN
}

\begin{abstract}
Laboratorio Vertebrados, Instituto de Investigaciones Marinas y Costeras (IIMyC), Facultad de Ciencias Exactas y Naturales, Consejo Nacional de Investigaciones Científicas y Técnicas, Universidad Nacional de Mar del Plata, Funes 3250, (7600) Mar del Plata, ARGENTINA

*Corresponding author, e-mail: acardoni@mdp.edu.ar
\end{abstract}

Cardoni D. A., Isacch J. P., Baladrón A. 2017. Causes and consequences of nest mass and structure variation in the Bay-capped Wren-spinetail Spartonoica maluroides. Acta Ornithol. 52: 51-58. DOI 10.3161/00016454AO2017.52.1.005

\begin{abstract}
Bay-capped Wren-Spinetail Spartonoica maluroides (Furnariidae) nests very close to the ground in dense clumps of grasses or sedges and builds both open and enclosed nest. We describe a proportion and characteristics of both types of nests and evaluate some causes that could force the construction of one nest architecture or another. In order to study the causes of this variation, we assessed the variability of nest types (architecture and size) and vegetation structure, and examined their consequences for breeding parameters in a population of Bay-capped Wren-Spinetail breeding in Spartina densiflora saltmarshes located at a coastal lagoon on Atlantic coast in east Argentina. We found that Bay-capped Wren-Spinetail builds nests enclosed and open with similar frequency within the same population and vegetation type. All nests were built with stems and grass leaves of $S$. densiflora. We found that open nests were built in sites with denser vegetation than enclosed nests. Nesting success and nest survival were not affected by nest architecture and size. The ability to adjust nest structure according to the vegetation density may be a strategy aimed at increasing nest concealment to reduce the temperature inside the nest or to avoid nest depredation. A flexible nest architecture strategy in Bay-capped Wren-spinetail is a possible adaptation to living in simple, yet structurally variable environments such as saltmarshes.
\end{abstract}

Key words: nest, characteristics of nest, Furnariidae, Spartonoica maluroides, Spartina densiflora, saltmarsh, breeding success, Argentina

Received - May 2016, accepted — March 2017

\section{INTRODUCTION}

Breeding is an important period of bird's life cycle. The nest is a key factor of successful breeding, since it provides shelter for eggs and nestlings and, in many cases, helps parents to conserve energy during the incubation and brooding stages (Collias \& Collias 1984). Nest construction is energetically expensive for birds (Withers 1977, Lens et al. 1994, Mainwaring \& Hartley 2013, Møller et al. 2014), affecting the energy investment during the incubation and nestling period (Moreno et al. 2010). Therefore, nest size may be subject to multiple trade-offs. While some selective factors favour large nests, due to maintenance of a specific nest temperature and humidity (Mainwaring et al. 2012), sexual selection (Palomino et al. 1998, Soler et al. 1998), clutch size (Møller 1982) and thermoregulation (Palomino et al. 1998, BoteroDelgadillo et al. 2017), whereas other factors favour small nests, due to a decrease in the risk of nest predation (Møller 1987), brood-parasitism (Soler et al. 1995), adult predation during nest construction (Slagsvold \& Dale 1996) and/or proliferation of pathogens and parasites (Stolp 1988).

Most furnariids breed in enclosed nests, either by building their nest inside a burrow, rock crevice, or tree hole, or by building domed nests (Vaurie 1980, Collias 1997). An exception may be the Bay-capped Wren-spinetail Spartonoica maluroides, that nesting very close to the ground amidst dense clumps of cordgrass Spartina densiflora and sedges Scirpus sp. and its nest vary in the degree of the elaboration of the roof (Narosky et al. 1983, Llambías et al. 2009, Cardoni et al. 2012). Wren-spinetail inhabits freshwater and brackish marshes in the Pampas region in north central Argentina, southeastern Brazil, and Uruguay (Ridgely \& Tudor 1994). Its nest architecture (open or enclosed) has been under controversy, since it has been considered as open by some authors 
(Durnford 1878, Hudson 1920, Pereyra 1938; see also Nores \& Yzurieta 1980, Vaurie 1980, Narosky et al. 1983, de la Peña 1988, Collias 1997) and as enclosed by others (Narosky 1973, Zyskowski \& Prum 1999, Dias et al. 2009). Llambías et al. (2009), suggested that Wren-spinetail builds both types of nests, with some nests having a rudimentary roof and others being open cups with few stems barely covering the top. This controversy about the openness of the Wren-spinetail nest was also noted by Vaurie (1980, 207p), who stated that "the open nest of $S$. maluroides is not so exceptional as it may seem, and I believe that $S$. maluroides probably also bred in a enclosed nest, although it is evident that its nesting behavior is breaking down for reasons which escape me completely...... I emphasize again that $S$. maluroides is the only furnariid species which breeds in an open nest, to my knowledge".

In order to investigate this controversy, we: (1) quantified nest variability in a population of the Wren-spinetail, with special emphasis on nest architecture (open or enclosed) and size, (2) analysed the relationship between vegetation structure and nest characteristics, and (3) assessed the effect of nest characteristics on breeding success. We hypothesize that the openness and size of the nest is regulated by vegetation structure. Thus, we predict that (1) open and smaller nests will be built in sites with high values of vegetation coverage and height, and (2) nests showing a combination of features that makes them more visible, such as lack of roof and bigger size, will have the lowest survival rates.

\section{METHODS}

\section{Study area}

The study was performed at the Mar Chiquita Coastal Lagoon Biosphere Reserve $\left(37^{\circ} 40^{\prime} \mathrm{S}\right.$, $57^{\circ} 23^{\prime} \mathrm{W}$ ) on the Atlantic coast in east Argentina. This reserve of 26,488 ha is part of the UNESCO Man and the Biosphere Program (Isacch 2008). The core zone is a publically-owned restricted area that consists of a coastal lagoon $\left(46 \mathrm{~km}^{2}\right)$ of low tidal amplitude (ca.1m) permanently connected to the sea (Reta et al. 2001), surrounded by marshes and grasslands (8600 ha). The main habitats around the lagoon are large saltmarshes dominated by Denseflower Cordgrass Spartina densiflo$r a$ and marshes dominated by Spiny Rush Juncus acutus and Pampas Grass Cortaderia selloana (Isacch et al. 2006).

\section{Nest and vegetation surveys}

We searched for Wren-spinetail nests during austral-summer 2011 in S. densiflora marshes, a habitat used by this species for breeding (Llambías et al. 2009, Cardoni et al. 2012). The nest search was conducted walking haphazardly within each area and through observations of reproductive behaviour, such as couple singing (Winter et al. 2003, Cardoni et al. 2012). We systematically searched from November 2010 to January 2011, which corresponds to the breeding period of the Wrenspinetail breeds in $S$. densiflora marshes (Cardoni et al. 2012). All nests were found in December, mostly in the incubation stage ( 24 incubating nests and 5 nestlings stage). Nests were marked using a colour tape placed $2 \mathrm{~m}$ to the $\mathrm{N}$ of the nest, and geopositioned using a GPS. Each nest was visited at intervals of 2-4 days to record the number of eggs, hatching date, fledging date, and events of nest predation (assumed when nests, eggs or nestlings were found damaged or removed). Standard procedures were followed to avoid attracting predators to nests, by (1) being quick and accurate during nest check, (2) minimizing the number of observers visiting the nest, (3) minimizing distress calls by adults and never allowing to continue for over $5 \mathrm{~min}$, (4) not approaching a nest when any potential nest predator (e.g. Chimango Caracara Milvago chimango, Falconidae) was present, (5) minimizing disturbance to the area around the nest, (6) not getting close to nests during nest building (Martin \& Geupel 1993). A nest was considered successful if one or more young fledged. With this information, we estimated clutch size, hatching success, and fledging success (Bart \& Robson 1982, Klett et al. 1986, Martin \& Geupel 1993).

In order to assess the relationship among nest architecture, nest mass, and nesting site we recorded the following variables: nest height above the ground $(\mathrm{NH})$ : measured from the ground to the base of the nest; vegetation height over the nest $(\mathrm{HON})$ : measured from base of the nest to the higher vegetation over nest; vegetation coverage (\%) at two different scales (VC1 at $1 \mathrm{~m}^{2}$ and VC2 at $4 \mathrm{~m}^{2}$ around the nest); average vegetation height around nest (VH): measured in a $1 \mathrm{~m}^{2}$ quadrant centered nest from the ground to the average vegetation high; and the Vegetation Obstruction Rate (VOR; Robel et al. 1970) recorded using a graduated pole $(9$ sections of $10 \mathrm{~cm}$, alternating between white and black) and reading the percentage of each section that could be viewed from a distance of $4 \mathrm{~m}$, always in the same 
direction, with the reader's eyes at a height of $1 \mathrm{~m}$. So higher VOR values denote site with low vegetation density. For analysis, VOR values were grouped at three heights over the ground $0-30 \mathrm{~cm}$ (VOR1), 31-60 cm (VOR2), and 61-90 cm (VOR3). All vegetation variables were measured the same day for all nests at the end of the breeding cycle, since the structure of $S$. densiflora (e.g. coverage and height) does not change significantly during the sampled period (Isacch \& Cardoni 2011, Cardoni et al. 2012).

We determined the nest architecture as: (1) enclosed: domed nests with roofs of interlaced stems (Fig. 1 A, B) or (2) open: open cup without roof (Fig. $1 \mathrm{C}, \mathrm{D})$. In order to avoid adult and/or nestling distress, and because we needed to weigh the nests by removing them from their base, nests measurements were taken after young fledged or when the nest was abandoned due to predation. All the nests were dried in an oven at $80{ }^{\circ} \mathrm{C}$ for 24 $\mathrm{h}$. The dry mass of the nests, a measure of nest size, was then determined using a digital balance
(0.5 g accuracy) to investigate its relationship with nest architecture and habitat structure.

\section{Statistical analyses}

First, we performed Student t-tests to evaluate the null hypothesis of no difference in vegetation structure (CV1, VH, VOR), nest location (HON, $\mathrm{NH}$ ) and nest mass (Nmass) between open and enclosed nests (Zar 2010).

Secondly, we constructed a correlation matrix with all variables to test for covariation among them. If Pearson correlation value (R) was higher than 0.5 , we arbitrarily selected the variable that resulted in the greatest separation in the a posteriori analysis. Four nest-site variables were selected: HON, NH, VOR3, and VC. Subsequently, we used Generalized Linear Models (GLMs) to identify which nesting variables best explain the nest architecture and nest mass. Specifically we tested the following relationships: 1) Effect of nest mass, nesting habitat and clutch size on nest architecture - we analyzed the effect of nesting

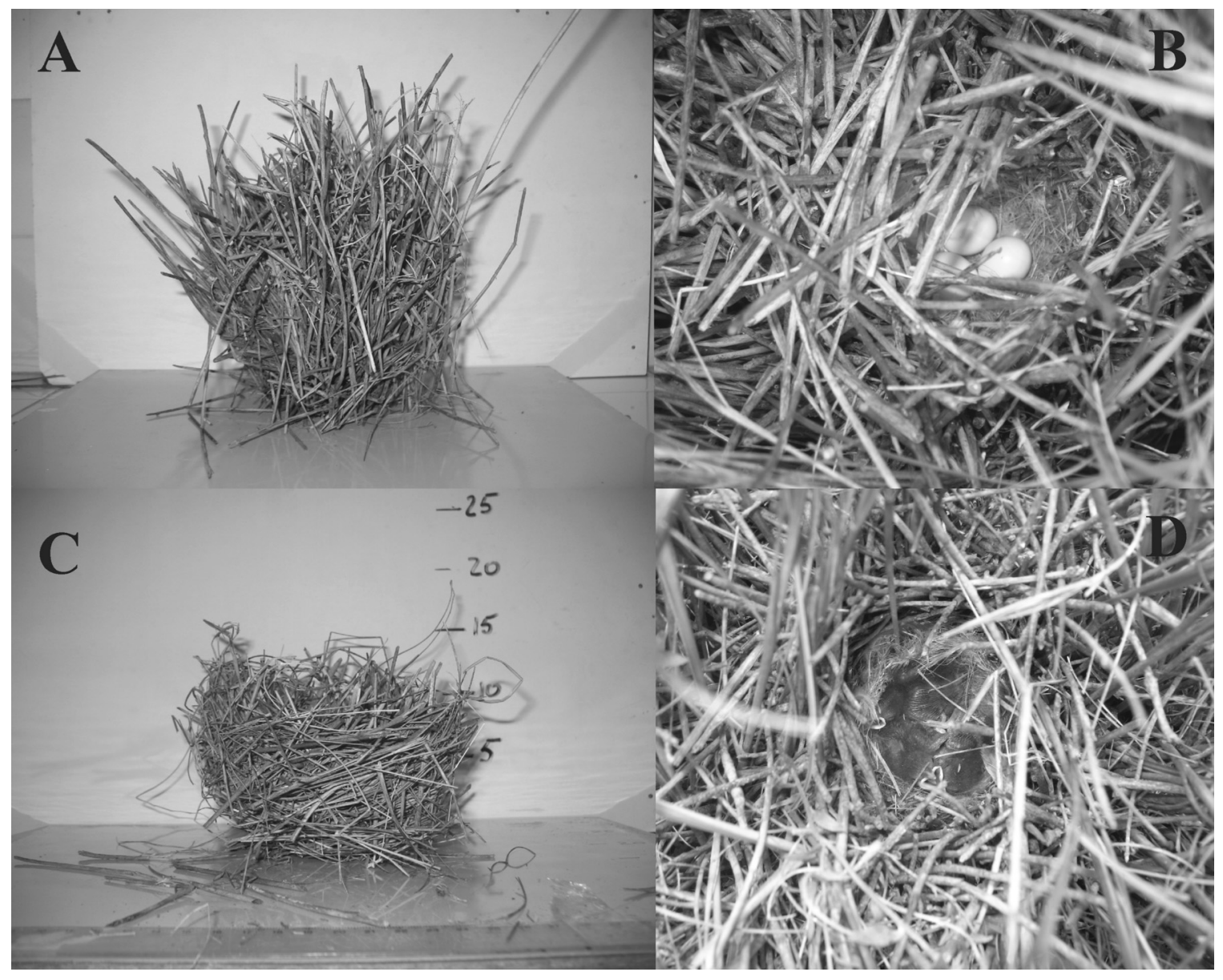

Fig. 1. Enclosed (A, B) and open nests (C, D) of the Bay-capped Wren-spinetail located in Spartina densiflora marshes. 
habitat features (VC, VOR3), nest location (HON, $\mathrm{NH}$ ), nest mass (Nmass) and clutch size (CS) on nest architecture (response variable). Since the response variable was binary (open vs. enclosed), we used a binomial error distribution with a logit link function (Crawley 2007); 2) Effect of nest architecture, nesting habitat and clutch size on nest mass - we analyzed the effect of habitat features (VC, VOR3), nest location ( $\mathrm{HON}, \mathrm{NH})$, nest architecture (NO) and clutch size (CS) on nest mass (response variable). For this analysis, we included the nest architecture as explanatory variable, using a Gaussian error distribution with a logit link function (Crawley 2007); 3) Effect of nest architecture and nest mass on the daily survival rate (DSR) - we used the nest survival models of the program MARK (White \& Burnham 1999) to estimate DSR and to test the effects of nest architecture (open vs. enclosed nest) and nest mass on DSR. Survival rates were compared between nest architectures by chi-square tests using CONTRAST software (Hines \& Sauer 1989).

We used the Akaike Information Criterion for small samples (AICc) to select the most explicative model/s (Burnham \& Anderson 1998, Franklin et al. 2001). Models with $\triangle$ AICc $<2$ were considered the most parsimonious and hence more robust to explain the observed variability. Goodness-of-fit for each model was evaluated by examining plots of standardized residuals, and the dispersion factor was checked in every case (Crawley 2007). For all analyses we used R software, Version 3.1.1 (R Development Core Team 2015).

\section{RESULTS}

\section{Nest description}

We found 29 nests of Wren-spinetails (12 open and 17 enclosed $-41 \%$ and $59 \%$ respectively; Fig. 1) which showed an average mass of $56.5 \mathrm{~g}$ $(\mathrm{SD}=25.8, \mathrm{n}=26$; Fig. 2). All nests were built almost entirely with stems and grass leaves of Spartina densiflora. The nest shape varied from globular to spherical, independently of the nest architecture. All nests were divided into two parts: an outer cluttered layer of stems of $S$. densiflora, and an internal cup-shaped incubation chamber.

\section{Nest structure and nest mass}

We found that enclosed nests were located in habitats with higher values of VOR3 (i.e., higher visibility) in comparison with open nests (Table 1).

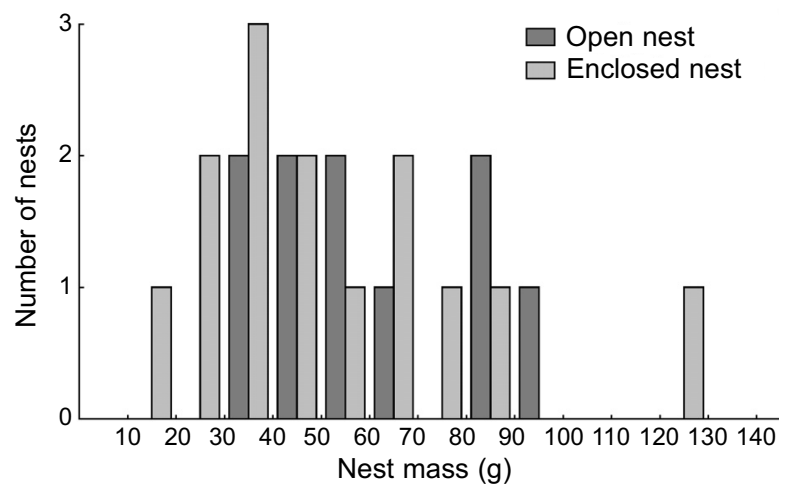

Fig. 2. Nest mass frequencies of the Bay-capped Wren-spinetail breeding in Spartina densiflora marshes.

Nest architecture was best explained (lowest AIC) by the model that included VOR3, but other models with $\triangle \mathrm{AIC}<2$ included $\mathrm{NH}$ and $\mathrm{HON}$, and HON and VOR3 (Table 2). Other variables related

Table 1. Comparison of breeding parameters, nest location and nesting habitat parameters for enclosed and open nest of Bay-capped Wren-spinetails breeding in Spartina densiflora saltmarshes. CS - clutch size, CF - number of chicks fledged, $\mathrm{NH}$ - nest height above the ground, $\mathrm{HON}$ - the vegetation height over the nest, $\mathrm{VC} 1$ - vegetation coverage at $1 \mathrm{~m}^{2}$ around the nest, $\mathrm{VC} 2$ - vegetation coverage at $4 \mathrm{~m}^{2}$ around the nest, $\mathrm{VH}$ - vegetation height at $1 \mathrm{~m}^{2}$ around the nest, VOR1 - Vegetation Obstruction Rate between $0-30 \mathrm{~cm}$ on the ground, VOR2 - Vegetation Obstruction Rate between 31-60 $\mathrm{cm}$ on the ground, VOR3 - Vegetation Obstruction Rate between $61-90 \mathrm{~cm}$ on the ground.

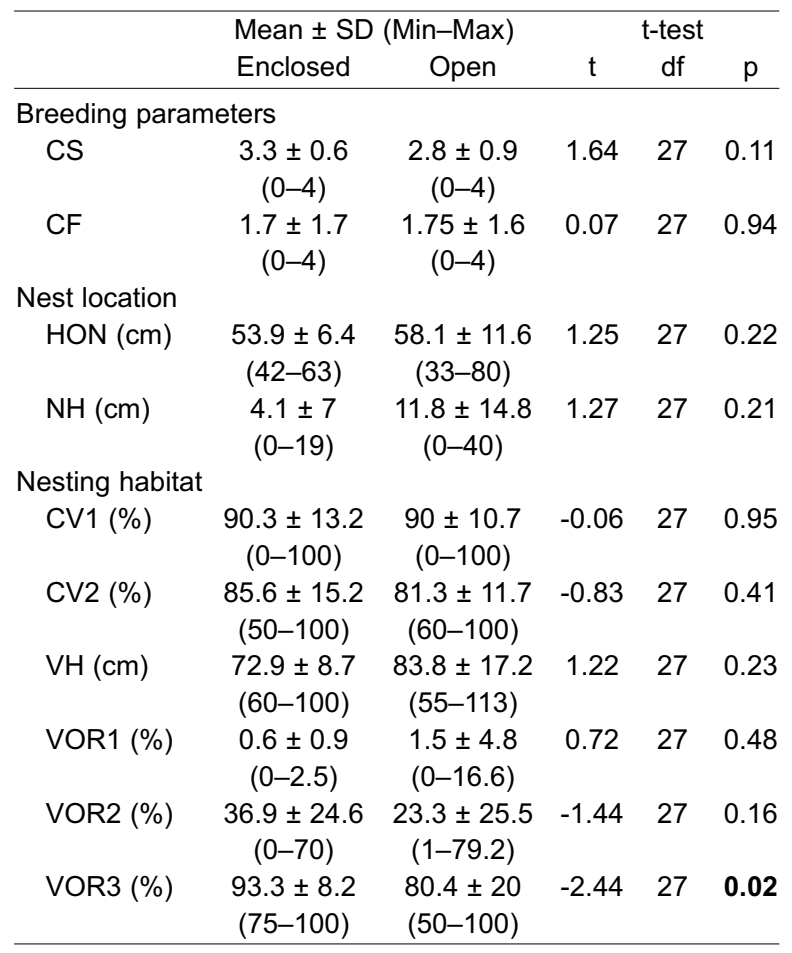


to nesting habitat (CV1, CV2, VH, VOR1 and VOR2), and nest location ( $\mathrm{HON}, \mathrm{NH})$ did not show differences between enclosed and open nests (Table 1). The average nest mass was similar between open and enclosed nests (respectively mean \pm SD: $56.4 \pm 25.2 \mathrm{~g}$ and $55.4 \pm 27.9 \mathrm{~g}$; t-test: $\mathrm{t}=0.10, \mathrm{df}=22, \mathrm{p}=0.92)$. The nest mass was best explained by the null model. Therefore, the nest mass did not show any relationship with nesting habitat structure, nest location variables, and nest architecture (Table 2).

\section{Breeding success}

The clutch size and the number of chicks fledged were similar between open and enclosed nests (Table 1). The DSR was 0.97 and 0.98 for enclosed and open nest respectively, and the probability to survive during the entire cycle (30 days, Cardoni et al. 2012) was 0.39 for enclosed nest $(S E=0.14)$ and 0.58 for open nests $(\mathrm{SE}=0.24)$. The values of survival rates did not differ significantly between both types of nest architecture $\left(\chi^{2}=0.46, \mathrm{df}=1\right.$, $\mathrm{p}=0.49$ ).

\section{DISCUSSION}

We found that Wren-spinetails build both enclosed and open nests in similar proportions

Table 2. Summary of model-selection results for candidate models explaining the variation in nest architecture and nest size of the Bay-capped Wren-Spinetail nesting in Spartina densiflora marshes. Variables included in the analysis: $\mathrm{VC}$ - vegetation cover; $\mathrm{NH}$ - nest height above the ground; HON - vegetation height over the nest, VOR3 - Vegetation Obstruction Rate between $61-90 \mathrm{~cm}$ on the ground, $\mathrm{N}_{\text {mass }}$ - nest mass, CS - clutch size. $k$ is the number of estimated parameters, $\triangle \mathrm{AICc}$ - the difference between the AICc value for the specified model and the model with the lowest AICc, $w_{i}$ - the model's weight. The null model, the global model (all explanatory variables listed above), and models with strong support $(\triangle \mathrm{AICc} \leq 2)$ are provided. The models are ordered by increased $\triangle \mathrm{AICc}$.

\begin{tabular}{lllll}
\hline & $k$ & AICc & $\Delta$ AICc & $w_{\mathrm{i}}$ \\
\hline Nest structure $(\mathrm{n}=29)$ & & & & \\
$\quad$ VOR3 & 2 & 38.2 & 0 & 0.139 \\
NH + HON & 3 & 39.5 & 1.3 & 0.073 \\
CS + VOR3 & 3 & 39.6 & 1.4 & 0.069 \\
HON + VOR3 & 3 & 39.8 & 1.5 & 0.09 \\
null & 1 & 41.5 & 3.3 & 0.038 \\
$\quad$ Global model & 6 & 47.9 & 9.7 & 0.002 \\
Nest mass $(\mathrm{n}=29)$ & & & & \\
null & 1 & 269.4 & 0 & 0.265 \\
CS & 2 & 271.2 & 1.8 & 0.106 \\
Global model & 6 & 283.8 & 14.4 & 0 \\
\hline
\end{tabular}

Table 3. Summary of model-selection results for candidate models explaining the Daily Survival Rate (DSR) of the Baycapped Wren-Spinetail nests located in Spartina densiflora marshes. Nest survival was modeled with the incorporation of covariates and compared with the null model of constant survival, $\mathrm{S}($.$) . The following variables were included in the analy-$ sis: nest openness (NO; open or enclosed nest) and nest mass $\left(\mathrm{N}_{\text {mass }}\right) . \mathrm{k}$ is the number of estimated parameters, $\triangle \mathrm{AICc}$ - the difference between the AICc value for the specified model and the model with the lowest AICc, $\mathrm{w}_{\mathrm{i}}$ - the model's weight. The models are ordered by increased $\triangle \mathrm{AIC}$.

\begin{tabular}{lcccc}
\hline & $k$ & AICc & $\Delta$ AICc & $w_{i}$ \\
\hline DSR $(\mathrm{n}=29)$ & & & & \\
$\quad$ null & 1 & 53.87 & 0 & 0.523 \\
$\mathrm{~N}_{\text {mass }}$ & 2 & 55.71 & 1.8 & 0.283 \\
$\mathrm{NO}$ & 2 & 55.87 & 2 & 0.192 \\
$\mathrm{~N}_{\text {mass }}+\mathrm{NO}$ & 3 & 57.71 & 3.8 & 0.076 \\
\hline
\end{tabular}

within the same population and vegetation type (Spartina densiflora). Nest architecture was explained by the vegetation obstruction rate between 61-90 cm (VOR3), indicating that vegetation structure modulated the shape of the nest. Nest architecture is a conservative character among birds (Vaurie 1980, Collias \& Collias 1984, Zyskowski \& Prum 1999), so the question arises why Wren-spinetail differ in nest building behavior. Nest construction is costly not only due to energetic and time demands (Hansell 2000) but also by increased predation risk during nest building (Collias \& Collias 1984). Nest size variation within a species could respond to several selective pressures, with some forces favouring small nests, such as predation and parasitism, and others favouring large nests, such as sexual display and thermoregulation (Palomino et al. 1998). Wrenspinetails breeding in Spartina densiflora marshes had a relatively high nesting success and low rate of predation (Llambías et al. 2009, Cardoni et al. 2012, this study) and we did not recorded parasitism, thus they do not appear to be selective forces capable of influencing the nest size. On the other hand, since both parents of Wren-spinetail build the nest (Remsen 2003, Cardoni et al. 2009, Llambías et al. 2009), it is not expected to find variation in nest size associated with sexual selection, one of the main processes favouring large nests (Palomino et al. 1998), since monogamy and biparental care would not select for showy male nests.

Alternative explanations for the wide variation in nest size found in Wren-spinetails could be related to temperatures regulation (BoteroDelgadillo et al. 2017). Saltmarshes experience 
elevated temperature during the breeding season (late spring and summer months, peak of $40^{\circ} \mathrm{C}$ ), so species living in saltmarshes use different strategies to reduce their body temperature. For example, emberiziid species breeding in North American saltmarshes have evolved large bills to increase heat loss (Greenberg et al. 2012). Following the same reasoning, we postulate that variation in the nest size of Wren-spinetails could be a strategy to reduce the temperature inside the nest. In this regard, we found that enclosed nests were placed in sites with low Spartina densiflora density surrounding the nest (high VOR values), so the presence of the roof may a flexible character to regulate nest temperature in relationship with vegetation density around it.

We suggest that variation in nest structure found for Wren-spinetails could be related with an evolutionary response leading to increased nest protection. This hypothesis predicts higher nest investment in sites with low vegetation structure (e.g. high VOR values) and vice-versa. In agreement with this prediction, we found that open nests were built more often in sites with more complex vegetation structure than were enclosed nests. For birds that nest in saltmarshes, the distance of the nest from the ground is an important variable influencing nest failure by both predation and flooding (DiQuinzio et al. 2002, Gjerdrum et al. 2005, Cardoni et al. 2012). Particularly, saltmarshes dominated by Spartina densiflora $(\sim 0.8 \mathrm{~m}$ height) are shorter than other tall-grasslands adjacent to the marsh (e.g. Cortaderia selloana $\sim 1.5 \mathrm{~m}$; Isacch et al. 2014). So that the range of heights at which Wren-spinetail nests may be placed is relatively narrow ( $\sim 40 \mathrm{~cm}$, Cardoni et al. 2012$)$ compared to other grasslands of the same region $(\sim 1.5$ $\mathrm{m}$, Isacch et al. 2014). This may determinate a trade-off between the effect of flooding and ground predation (affecting nests placed in lower strata) and the effect of aerial predation (affecting nests placed in higher strata). Despite these limitations, the nesting success of Wren-spinetails breeding in marshes dominated by Spartina densiflora is relatively high ( $\sim 58 \%$, Llambías et al. 2009 , Cardoni et al. 2012, this study), compared to other species nesting in the same environment, such as the Grassland Yellow-Finch Sicalis luteola, the Great Pampa Finch Embernagra platensis, and the Chimango Caracara Milvago chimango ( $10 \%$, Cardoni 2011). Wren-spinetail's nesting strategy seems to be relatively successful. We suggest that the ability to adjust the nest structure according to the vegetation density would be associated to increase nest concealment thus ensuring a similar reproductive performance.

Intraspecific variation in nest architecture and placement are correlated with proximate biotic and abiotic factors (Collias \& Collias 1984, Kern \& van Riper 1984, Zyskowski \& Prum 1999), governed by genetic (adaptive) and environmental components. In this sense, the Spartina saltmarshes where Wren-spinetails breed (Llambías et al. 2009, Cardoni et al. 2012, 2013) were shaped during the late Pleistocene (Milá et al. 2006, Ruegg et al. 2006). Rapid change in the availability of habitat with the receding of Pleistocene glaciers is thought to have driven rapid and extensive expansion of populations, which might select for rapid morphological and ecological divergence (Milá et al. 2006, Ruegg et al. 2006). Entry into a new environment results in selective pressures favoring divergence from the ancestor, and could be accompanied by behavioral and other plastic forms of accommodation, and this will usually be followed by selection in the context of these changes (Price et al. 2003). Several studies have shown that some bird species have adapted to the conditions presented by the marshes, for example, increment in beak size to increase heat body loss (Greenberg et al. 2012), changes in the performance of the song as mating signals (Ballentine 2006), changes in body sizes (Greenberg \& Droege 1990, Grenier \& Greenberg 2006), and plumage melanism (Greenberg \& Droege 1990). Recently, it has been reported that Wren-spinetail populations that breed in coastal marshes (dominated by Spartina densiflora) show phenotypic differences in bill morphology and plumage coloration (melanism) in respect to populations breeding at inland marshes (Cardoni et al. 2013). This suggests that different selective forces would be acting on Wren-spinetail's traits, which may induce changes in important aspects of its life history, such as foraging (Cardoni et al. 2013) or nesting strategies (this study).

An open nest is a novel feature for a furnariid species, since an enclosed nest is the ancestral condition in this family (Vaurie 1980, Zyskowski \& Prum 1999). Clearly, the nest of Wren-spinetail presents a different structure to the others furnariid species, which strictly built enclosed nests, and, in many cases, with greater structural complexity, including tunnels, entrance tubes, and thatches (Zyskowski \& Prum 1999). This simplicity of open nests of Wren-spinetails in comparison to other furnariids could be partially related to vegetation complexity. However, it is noteworthy that 
other furnariid species that inhabit grasslandmarsh habitats build enclosed nests (e.g. Limnornis curvirostris, Limnoctites rectirostris, Phleocryptes melanops, Cranioleuca sulphurifera; Narosky et al. 1983, de la Peña 1988), thus indicating either phylogenetic constraints on nest architecture evolution or differences in the characteristics of nest sites. In any case, evolution seems to have favored a flexible strategy in Wren-spinetail in terms of the nest architecture, as a possible adaptation to live in a structurally variable environment, such as saltmarshes (Cardoni et al. 2013, Isacch et al. 2014).

\section{ACKNOWLEDGEMENTS}

We thank Mercedes Fernández Alegría for help during field work. Also, we appreciate the improvements in English usage and comments made by Santiago Claramunt. We also thank two anonymous referees for providing helpful comments on the manuscript. Financial support was provided by the Consejo Nacional de Investigaciones Científicas y Técnicas (CONICET), Agencia Nacional de Promoción Científica y Tecnológica (Argentina), Universidad Nacional de Mar del Plata, and Neotropical Grassland Conservancy.

\section{REFERENCES}

Ballentine B. 2006. Morphological adaptation influences the evolution of a mating. Evolution 60: 1936-1944.

Bart J., Robson D. S. 1982. Estimating survivorship when the subjects are visited periodically. Ecology 63: 10781090.

Botero-Delgadillo E., Orellana N., Serrano D., Poblete Y., Vásquez R. A. 2017. Interpopulation variation in nest architecture in a secondary cavity-nesting bird suggests sitespecific strategies to cope with heat loss and humidity. Auk 134: 281-294.

Burnham K. P., Anderson D. R. 1998. Model selection and inference: A practical information theoretic approach. SpringerVerlag, New York.

Cardoni D. A. 2011. Evolutionary adaptations and responses to anthropic activity of birds at southwest Atlantic marshlands: an analysis at different temporal scales. Ph.D. thesis, University of Mar del Plata, Argentina.

Cardoni D. A., Greenberg R., Maldonado J. E., Isacch J. P. 2013. Morphological adaptation to coastal marshes in spite of limited genetic structure in the Neotropical passerine Spartonoica maluroides (Aves: Furnariidae). Biol. J. Linn. Soc. 109: 78-91.

Cardoni D. A., Isacch J. P., Iribarne O. O. 2012. Effects of cattle grazing and burnings on the abundance, habitat selection, and nesting success of the bay-capped wren-spinetail (Spartonoica maluroides) in coastal saltmarshes of the Pampas region. Condor 114: 803-811.
Cardoni D. A., Maldonado J. E., Isacch J. P., Greenberg R. 2009. Subtle sexual dimorphism in the Bay-capped WrenSpinetail (Furnariidae) uncovered through molecular sex determination. Ornitol. Neotrop. 20: 347-355.

Collias N. E. 1997. On the origin and evolution of nest building by passerine bird. Condor 99: 253-270.

Collias N. E., Collias E. C. 1984. Nest building and bird behavior. Princeton University Press, Princeton.

Crawley M. J. 2007. The R Book. Wiley, Chichester.

De la Peña R. M. 1988. [Guide of Argentinean birds]. Literature of Latin America (L.O.L.A.), Buenos Aires.

Dias R. A., Gonçalves M. S. S., Bastazini V. A. G. 2009. First nesting record of the Bay-capped Wren-Spinetail Spartonoica maluroides (Aves, Furnariidae) in Brazil, with nest and nestling descriptions and notes on breeding behavior. Iheringia Ser. Zool. 99: 449-455.

DiQuinzio D. A., Paton P. W. C., Eddleman W. R. 2002. Nesting ecology of saltmarsh Sharp-tailed Sparrows in a tidally restricted salt marsh. Wetlands 22: 179-185.

Durnford H. 1878. Notes on the birds of the Province of Buenos Ayres. Ibis 2: 58-68.

Franklin A. B., Shenk T. M., Anderson D. R., Burnham K. P. 2001. Statistical model selection: an alternative to null hypothesis testing. In: Shenk T. M., Franklin A. B. (eds). Modeling in natural resource management: development, interpretation, and application. Island Press, Washington, pp. 75-90.

Gjerdrum C., Elphick C. S., Rubega M. 2005. Nest site selection and nesting success in saltmarsh breeding sparrows: The importance of nest habitat, timing, and study site differences. Condor 107: 849-862.

Greenberg R., Danner R. M., Olsen B. J., Luther D. 2012. High summer temperature explains bill size variation in salt marsh sparrows. Ecography 35: 146-152.

Greenberg R., Droege S. 1990. Adaptations to tidal marshes in breeding populations of the Swamp Sparrow. Condor 92: 393-404.

Grenier J. L., Greenberg R. 2006. Trophic adaptations in sparrows and other vertebrate of tidal marshes. In: Greenberg R., Maldonado J., Droege S., McDonald M. V. (eds). Terrestrial vertebrates of tidal marshes: Evolution, ecology and conservation. Stud. Avian Biol. 32: 130-139.

Hansell M. 2000. Bird nests and construction behaviour. Cambridge University, Cambridge.

Hines J. E., Sauer J. R. 1989. Program CONTRAST — A general program for the analysis of several survival or recovery rate estimates. US Fish and Wildlife Service, Fish and Wildlife Technical Report 24, Washington.

Hudson W. H. 1920. Birds of La Plata. Vol. 1. J. M. Dent and Sons, Ltd., London.

Isacch J. P. 2008. Implementing the biosphere reserve concept: the case of Parque Atlántico Mar Chiquito biosphere reserve from Argentina. Biodivers. Conserv. 17: 1799-1804.

Isacch J. P., Cardoni D. A., Iribarne O. O. 2014. Diversity and habitat distribution of birds in coastal marshes and comparisons with surrounding upland habitats in southeastern South America. Estuar. Coast. 37: 229-239.

Isacch J. P., Costa C. S. B., Rodríguez-Gallego L., Conde D., Escapa M., Gagliardini D. A., Iribarne O. O. 2006. Association between distribution pattern of vascular plants and environmental factors in SW Atlantic saltmarshes. J. Biogeogr. 33: 888-900.

Kern M. D., van Riper III C. 1984. Altitudinal variations in nests of the Hawaiian Honeycreeper Hemignathus virens virens. Condor 86: 443-454.

Klett A. T., Duebbert H. F., Faanes C. A., Higgins K. F. 1986. Techniques for studying nest success of ducks in upland habitats in the Prairie Pothole Region. US Fish and Wildlife Service, Resource Publication 158. 
Lens L., Wauters L. A., Dhondt A. A. 1994. Nest building by Crested Tit Parus cristatus males: an analysis of costs and benefits. Behav. Ecol. Sociobiol. 35: 431-436.

Llambías P. E., Ferretti V., Cardoni D. A., Maldonado J. E. 2009. Breeding success and social mating system of the Baycapped Wren-Spinetail (Spartonoica maluroides). Wilson J. Ornithol. 121: 803-807.

Mainwaring M. C., Hartley I. R. 2013. The energetic costs of nest building in birds. Avian Biol. Res. 6: 2-17.

Mainwaring M. C., Hartley I. R., Bearhop S., Brulez K., du Feu C. R., Murphy G., Plummer K. E., Webber S. L., Reynolds S. J., Deeming D. C. 2012. Latitudinal variation in blue tit and great tit nest characteristics indicates environmental adjustment. J. Biogeogr. 39: 1669-1677.

Martin T. E., Geupel G. R. 1993. Nest-monitoring plots: methods for locating nests and monitoring success. J. Field Ornithol. 64: 507-519.

Milá B., Smith T. B., Wayne R. K. 2006. Postglacial population expansion drives the evolution of long-distance migration in a songbird. Evolution 60: 2403-2409.

Møller A. P. 1982. Clutch size in relation to nest size in the Swallow Hirundo rustica. Ibis 124: 339-343.

Møller A. P. 1987. Egg predation as a selective factor for nest design: an experiment. Oikos 50: 91-94.

Møller A. P., Adriaensen F., Artemyev A., Banbura J., et al. 2014. Clutch size in European secondary hole-nesting passerines in relation to nest-box floor area, habitat, geographic location and study year. Methods Ecol. Evol. 5: 353-362.

Moreno J., Lobato E., González-Braojos S., Ruiz-De Castayeda R. 2010. Nest construction costs affect nestling growth: a field experiment in a cavity-nesting passerine. Acta Ornithol. 45: 139-145.

Narosky S. 1973. Observations on the nesting of Spartonoica maluroides. Ibis 115: 142-143.

Narosky T., Fraga R., de la Peña M. 1983. [Nesting of Argentinean birds (Dendrocolaptidae and Furnariidae)]. Asociación Ornitológica del Plata, Buenos Aires, Argentina.

Nores M., Yzurieta D. 1980. [Birds of aquatic environments from Córdoba and central Argentina]. Secretaria de Estado de Agricultura y Ganadería, Córdoba, Argentina.

Palomino J. J., Martin-Vivaldi M., Soler M., Soler J. J. 1998. Functional significance of nest size variation in the Rufous Bush Robin (Cercotrichas galactotes). Ardea 86: 177-185.

Pereyra J. A. 1938. [Birds of the northeast riparian zone of Buenos Aires Province]. Memorias del Jardín Zoológico de La Plata 9: 1-304.

Price T. D., Qvarnström A., Irwin D. E. 2003. The role of phenotypic plasticity in driving genetic evolution. Proc. R. Soc. Lond. B 270: 1433-1440.

R Development Core Team 2015. R: a Language and Environment for Statistical Computing. R Foundation for Statistical Computing: Vienna, Austria, available at http://www.r-project.org

Remsen J. 2003. Family Furnariidae (Ovenbirds). In: del Hoyo J., Elliott A., Christie D. (eds). Handbook of the Birds of the World. Vol. 8: Broadbills to Tapaculos. Lynx Edicions, Barcelona, Spain, pp. 162-357.

Reta R., Martos P., Perillo G. M. E., Piccolo M. C., Ferrante A. 2001. [Hydrographic features of Mar Chiquita lagoon estuary]. In: Iribarne O. (ed.). Mar Chiquita Biosphere Reserve. Editorial Martín, Mar del Plata, Argentina, pp. 31-52.

Ridgely R. S., Tudor G. 1994. The birds of South America: the suboscine passerines. University of Texas Press, Austin.

Robel R. J., Briggs J. N., Dayton A. D., Hulbert L. C. 1970. Relationships between visual obstruction measurements and weight of grassland vegetation. J. Range Manage. 23: 295-297.
Ruegg K. C., Hijmans R. J., Moritz C. 2006. Climate change and the origin of migratory pathways in the Swainson's thrush, Catharus ustulatus. J. Biogeogr. 33: 1172-1182.

Slagsvold T. Dale S. 1996. Disappearance of female pied flycatchers in relation to breeding stage and experimentally induced molt. Ecology 77: 461-471.

Soler J. J., Møller A. P., Soler M. 1998. Nest building, sexual selection and parental investment. Evol. Ecol. 12: 427-441.

Soler J. J., Soler M., Møller A. P., Martínez J. G. 1995. Does the great spotted cuckoo choose magpie hosts according to their parenting ability? Behav. Ecol. Sociobiol. 36: 201-206.

Stolp H. 1988. Microbial ecology: organisms, habitats, activities. Cambridge Univ. Press, Cambridge, UK.

Vaurie C. 1980. Taxonomy and geographical distribution of the Furnariidae (Aves, Passeriformes). Bull. Am. Mus. Nat. Hist. 166: 1-357.

White G. C., Burnham K. P. 1999. Program MARK: survival estimation from populations of marked animals. Bird Study 46: $120-138$.

Winter M., Hawks S. E., Shaffer J. A., Johnson D. H. 2003. Guidelines for finding nests of passerine birds in tallgrass prairie. USGS Northern Prairie Wildlife Research Center.

Withers P. C. 1977. Energetic aspects of reproduction by the cliff swallow. Auk 94: 718-725.

Zar J. H. 2010. Biostatistical analysis. 5th edition. Pearson Prentice-Hall, Upper Saddle River.

Zyskowski K., Prum R. O. 1999. Phylogenetic analysis of the nest architecture of neotropical ovenbirds (Furnariidae). Auk 116: 891-911.

\section{STRESZCZENIE}

\section{[Przyczyny i skutki budowy dwóch typów gniazd u widlaczków]}

Widlaczki (rodzina garncarzowate) gniazdują tuż nad ziemią w gęstych kępach traw lub sitowia, budując zarówno typowe gniazda otwarte, jak i gniazda zamknięte od góry (Fig. 1). W pracy opisano częstość występowania obu typów gniazd w populacji widlaczków gniazdujących w słonoroślach na atlantyckim wybrzeżu Argentyny, oraz podjęto próbę określenia przyczyn budowania przez ptaki jednego lub drugiego typu gniazda. W tym celu opisano masę gniazd obu typów oraz wysokość umiejscowienia gniazda nad ziemią oraz wysokość i strukturę roślinności wokół gniazd. $\mathrm{W}$ analizach uwzględniono także parametry rozrodu.

Stwierdzono, że w badanej populacji widlaczki budują gniazda zamknięte i otwarte $\mathrm{z}$ podobną częstością, a zmienność masy gniazd jest podobna (Fig. 2). Masa gniazda była niezależna od jego umiejscowienia oraz struktury roślinności. Gniazda otwarte były budowane $\mathrm{w}$ miejscach o większym zagęszczeniu roślinności niż gniazda zamknięte (Tab. 1, 2). Sukces lęgowy i dzienne prawdopodobieństwo przeżycia lęgu (DSR) nie były związane $\mathrm{z}$ typem gniazda ani jego wielkością (Tab. 3). 